\title{
The Concept of Debulking in Ovarian Cancer
}

\author{
ALEXANDRA-LIGIA DINCA ${ }^{1}$, VALERIU-GABI DINCA ${ }^{2}$, \\ RODICA DANIELA BIRLA ${ }^{3 *}$, SILVIU MARIAN CONSTANTINOIU ${ }^{3}$ \\ ${ }^{1}$ Medicover Hospital Bucharest, 24 Preciziei Blvd., 062203, Bucharest, Romania. \\ ${ }^{2}$ Titu Maiorescu University Bucharest, 22 Dambovnicului Str., 041507, Bucharest, Romania \\ ${ }^{3}$ Carol Davila University Bucharest, 8 Eroii Sanitari, 050474, Bucharest, Romania
}

\begin{abstract}
Ovarian cancer is the most lethal gynecological oncological condition. He responds to primary surgical treatment, although the vast majority of patients are diagnosed in advanced stages of the disease, in which the rate of recurrences is increased and the chance of survival at 5 years is below $45 \%$.
\end{abstract}

Keywords: ovarian cancer, primary surgical treatment, increased relapse rate

\section{Introduction}

Although the subject of early detection of ovarian cancer has been widely studied worldwide lately, no diagnostic method has yet been found to help diagnose early stages of the disease, so that patients come to the doctor when the abdomen is enlarged (due to the presence of the ascites), already signify an advanced stage of the disease. Therefore, most of the times, the surgeon is confronted with the advanced intraoperative stage of the disease, disseminated, in which the maximum tumor cytoreduction is difficult to obtain [1,2].

In Japan, at the 4th edition of the meeting of the Japanese Society of Gynecological Oncology in 2015 , in which the options for improving the prognosis of ovarian cancer were discussed, it was established that the primary treatment of epithelial ovarian cancer should be surgical: Intraoperative staging and Surgical eradication (Staging and Debulking), followed by adjuvant chemotherapy treatment, with appropriate follow-up [3].

For the incipient stages, the International Federation of OG recommends the extraction of the intact tumor - Total hysterectomy with bilateral anexectomy, infracolic omentectomy, pelvic and aortic lymphadenectomy and biopsy of any suspicious tumors. If it is necessary, it will can be performed hemicolectomies, peritonectomies and exenterations [4].

The main purpose of cytoreductional surgery is macroscopic disease eradication, but the debate that remains is whether patients in advanced stages of the disease should benefit from primary or interval surgical treatment. According to the latest trials of patients studied, it was established that patients with operable disease per-primam and with good general status should benefit from primary cytoreductive surgical treatment, and patients with biological status affected (associated comorbidities, modified bio-humoral balance) or with the disease advanced disseminated will benefit from chemotherapy per primam, followed by interval surgery [5].

Theoretical support underlying the concept of "debulking" with adjuvant chemotherapy is related to the ability of chemotherapeutic agents to destroy the remaining malignant cells, because it is well known that the large remaining tumors have a poor central vascularization, such that the chemotherapist agents will penetrate with difficulty there or not at all [1].

The principles of citoreductional surgery in front of an ovarian neoplasm were first developed in 1934 by Meigs and have remained unchanged until now, except for the absolute value of the postoperative residual volume, which has decreased over time. Initially the target tumor volume is considered obtained should be $1.5 \mathrm{~cm}$ maximum and at present the optimal surgery is considered if the residual tumor diameter is less than $0.5 \mathrm{~cm}$ and suboptimal if the diameter exceeds $1 \mathrm{~cm} \mathrm{[6].}$

\footnotetext{
*email: gaby_uk30@yahoo.com
} 
According to a recent study published by Eisenkop, the goal of debulking interventions should be complete cytoreduction (macroscopic residual tumor absent $=$ residual tumor smaller than $0.5 \mathrm{~cm}$ ), and not optimal, because the patients followed up who had the complete intervention had a better survival than those with optimal surgery, which demonstrates that the absence of the absent macroscopic tumor is the most important prognosis factor of long-term survival [1].

Cytoreductive surgery is best performed by surgeons specialized in gynecological oncology and a multidisciplinary team that manages the treatment proves an improvement to the quality of life and the survival of the patients [7].

In this regard, Bristow et al were able to demonstrate in a study of 6885 patients operated for stage III / IV ovarian neoplasm FIGO that patients who received complete cytoreduction had a $5.5 \%$ increase in the median survival rate, which we can translate by an increase of 2-3 months, compared to the patients who have undergone optimal surgery [8-10].

\section{Material and method}

We made a retrospective study consisting of a group of 82 pacients diagnosed with ovarian carcinoma between 2010-2018 in General and Esophageal Surgery Clinic, Bucharest.

The data was obtained from hospitalization sheets, surgical protocols, hystopathologic results, oncologic personal history. The study included 82 pacients with the aged between 40 and 85 years old.

We analyzed the following clinical factors: age, reproductive status, the presence of the pelvic pain and vaginal bleeding; paraclinically factors: CA 125, imagistic findings: CT, RMN, abdominal and pulmonary radiography, colonoscopic findings; presurgical factors: stage of the disease and hystopathological resultsl tumoral factors: hystopathological type and tumoral grading; therapeutical factors: surgical resection type: optimal/suboptimal/complex surgery, oncologic treatments, the presence of postsurgical complications and the period of hospitalization.

Surgical treatment has as purpose maximal citoreduction, according to the latest recommendations of the International Federation of Obstetrics and Gynecology. The surgical treatment of ovarian carcinoma is standardized and divided in optimal and suboptimal surgery according to the presence and the macroscopic dimensions of the residual tumor after surgery. In fact, we call optimal surgery when the residual tumor after surgery is infracentrimetric and suboptimal when the residual tumor is bigger than 1 centimeter.

\section{Statistical analysis}

The tests Mann-Whitney U, LikelihoodRatio, PearsonChi-Square, Fisher's Exact were used to evaluate the associations between the clinical, surgical and pathological characteristics and the type of surgical resection.

The survival of the patients was defined as the period between the diagnosis of the disease and the death or the end of the period of following in the study (1.11.2019). The survival curves were calculated using Long-rank test. The statistical analysis was realised using SPSS software, version 23.0, and $\mathrm{p}$ under value 0.05 was considerated significant statistically.

\section{Results and discussions}

In the category of optimal surgery we included the incipient cases were macroscopic eradication was performed and in the category of complex surgery we included the advanced cases were pelvic and lomboaortic limfadenectomy, peritonectomy, rectosigmoidectomy or appendix excizion were performed. We defined suboptimal surgery the cases where the residual tumor was bigger than $1 \mathrm{~cm}$. 


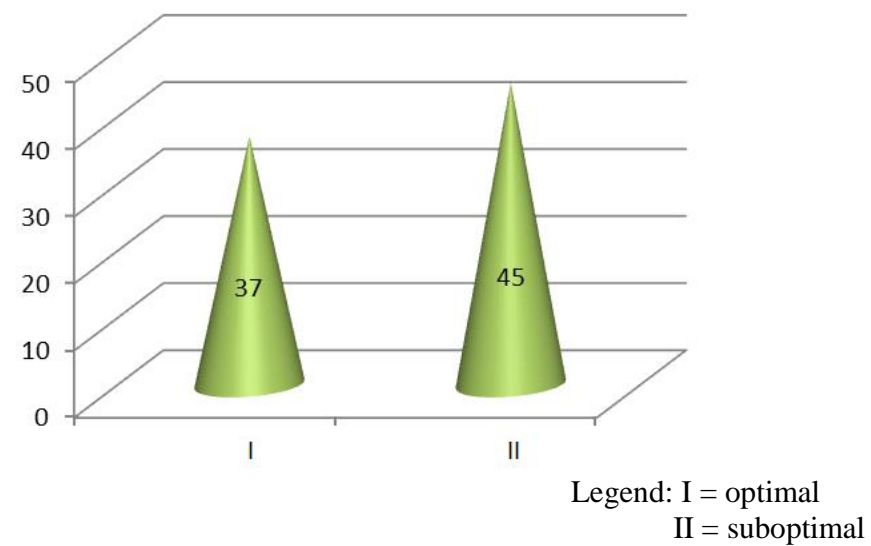

Figure 1. The allocation of the patients

according to the type of surgical treatment

Table 1. The correlation between the type of surgery and the paraclinically characteristics of the patiens.

\begin{tabular}{|c|c|c|c|}
\hline & \multicolumn{2}{|c|}{ Type of intervention } & \multirow[t]{2}{*}{$P_{\text {_value }}$} \\
\hline & $\mathrm{O}(\mathrm{N}=37)$ & $\mathrm{S}(\mathrm{N}=45)$ & \\
\hline $\begin{array}{c}\mathrm{Ca} 125 \\
0 \\
1 \\
2 \\
3\end{array}$ & $\begin{array}{l}32 / 36(88.9 \%) \\
3 / 36(8.3 \%) \\
0 / 36(0.0 \%) \\
1 / 36(2.8 \%)\end{array}$ & $\begin{array}{c}29 / 43(67.4 \%) \\
4 / 43(9.3 \%) \\
8 / 43(18.6 \%) \\
2 / 43(4.7 \%)\end{array}$ & $\begin{array}{c}0.011197 \\
\text { (Likelihood Ratio) }\end{array}$ \\
\hline $\begin{array}{c}\text { Imag - Pelvic tumor/Carcinoma } \\
\text { Carcinomatosis } \\
\text { Pelvic tumor } \\
\text { Pelvic tumor + Carcinomatosis }\end{array}$ & $\begin{array}{c}3 / 24(12.5 \%) \\
21 / 24(87.5 \%) \\
0 / 15(0.0 \%) \\
\end{array}$ & $\begin{array}{c}10 / 28(35.7 \%) \\
16 / 28(57.1 \%) \\
2 / 28(7.1 \%) \\
\end{array}$ & $\begin{array}{c}0.028455 \\
\text { (Likelihood Ratio) }\end{array}$ \\
\hline $\begin{array}{c}\text { Imag -Carcinomatosis } \\
\text { Carcinomatosis }\end{array}$ & $3 / 24(12.5 \%)$ & $12 / 28(42.9 \%)$ & $\begin{array}{c}0.016005 \\
\text { (Pearson Chi-Square) }\end{array}$ \\
\hline $\begin{array}{l}\text { Imag - Pelvic tumor } \\
\text { Pelvic tumor }\end{array}$ & $21 / 24(87.5 \%)$ & $18 / 28(64.3 \%)$ & $\begin{array}{c}0.053949 \\
\text { (Pearson Chi-Square) }\end{array}$ \\
\hline $\begin{array}{c}\text { Lungs radiography } \mathrm{N} / \text { secondary } \\
\text { determinations }=\text { Yes }\end{array}$ & $0 / 37(0.0 \%)$ & $3 / 45(6.7 \%)$ & $\begin{array}{c}0.247967 \\
\text { (Fisher's Exact Test) }\end{array}$ \\
\hline Abdominal x-ray imag ha=Yes & $3 / 5(60.0 \%)$ & $1 / 2(50.0 \%)$ & $\begin{array}{c}1.000000 \\
\text { (Fisher's Exact Test) }\end{array}$ \\
\hline Colonoscopy $=$ Patol & $3 / 5(60.0 \%)$ & $3 / 8(37.5 \%)$ & $\begin{array}{c}0.592075 \\
\text { (Fisher's Exact Test) }\end{array}$ \\
\hline
\end{tabular}

Comparing the group of the optimal surgery cases (37) with the group of the suboptimal sugery cases (45) we found out a significant association between high value of CA 125 and the type of suboptimal sugery, $\left(p_{-}\right.$value $=0.011197$ test Likelihood Ratio), imagistic finding of pelvic tumor and the type of optimal surgery, ( $p_{-}$value $=0.028455$ test Likelihood Ratio), imagistic finding of carcinomatosis and the type of suboptimal surgery, (p_value $=0.016005$ test Pearson Chi-Square) and radiographyc abdominal and pulmonary and colonoscopic findings and the type of surgery (Table 1).

Table 2. The correlation between the type of surgery and the FIGO stage of the disease

\begin{tabular}{|c|c|c|c|}
\hline \multirow{2}{*}{ The stage of the disease } & \multicolumn{2}{|c|}{ Type of intervention } & P_value \\
\cline { 2 - 3 } (test)
\end{tabular}

Considering the study groups, we found out a significant relanshionship between: 
- early stages of the disease ( stage I and II FIGO) and optimal surgery.

- advanced-stages of the disease and suboptimal surgery. ( $p$ value $=0,000019$ test Likelihood Ratio) (Table 2 ).

Table 3. The correlation between the type of surgery

\begin{tabular}{|c|c|c|c|}
\hline & \multicolumn{2}{|c|}{ Type of intervention } & \multirow{2}{*}{$\begin{array}{c}P_{\text {(test) }} \\
\end{array}$} \\
\hline & $\mathrm{O}(\mathrm{N}=37-45.1 \%)$ & $\mathrm{S}(\mathrm{N}=45-54.9 \%)$ & \\
\hline HP type & & & 0.050213 \\
\hline Clear cells & $0 / 34(0.0 \%)$ & $1 / 40(2.5 \%)$ & (Likelihood Ratio) \\
\hline endometrioid & $1 / 34(2.9 \%)$ & $1 / 40(2.5 \%)$ & \\
\hline canker & $3 / 34(8.8 \%)$ & $0 / 40(0.0 \%)$ & \\
\hline mucinous & $8 / 34(23.5 \%)$ & $3 / 40(7.5 \%)$ & \\
\hline undifferentiated & $5 / 34(14.7 \%)$ & $5 / 40(12.5 \%)$ & \\
\hline serous & $17 / 34(50.0 \%)$ & $30 / 40(75.0 \%)$ & \\
\hline Grading & & & 0.019507 \\
\hline 1 & $0 / 23(0.0 \%)$ & $6 / 33(18.2 \%)$ & (Likelihood Ratio) \\
\hline 2 & $2 / 23(8.7 \%)$ & $5 / 33(15.2 \%)$ & \\
\hline 3 & $21 / 23(91.3 \%)$ & $22 / 33(66.7 \%)$ & \\
\hline
\end{tabular}

Comparing the group of the optimal versus suboptimal surgery type cases we obtained a significant association between the serous histopathological type and suboptimal surgery (75\%), ( $\mathrm{p}_{-}$value $=0.050213$ test Likelihood Ratio), tumoral grading 1 and suboptimal surgery (18.2\%), tumoral grading 3 and optimal surgery, $(91,3 \%)\left(\mathrm{p} \_\right.$value $=0.019507$ test Likelihood Ratio), maybe because of the high frequency of the indifferented tumors (Tabel 3).

Table 4. The correlation between the type of surgery and postsurgical results

\begin{tabular}{|c|c|c|c|}
\hline & $\begin{array}{l}\text { Type of intervention } \\
\mathrm{O}(\mathrm{N}=37-45.1 \%)\end{array}$ & $\mathrm{S}(\mathrm{N}=45-54.9 \%)$ & $\begin{array}{l}\text { P_value } \\
\text { (test) }\end{array}$ \\
\hline Relapse $=$ Yes & $2 / 37(5.4 \%)$ & $10 / 45(22.2 \%)$ & $\begin{array}{l}0.032035 \\
\text { (Pearson Chi-Square) }\end{array}$ \\
\hline $\begin{array}{l}\text { Early postoperative complications } \\
=\text { Yes }\end{array}$ & $9 / 37(24.3 \%)$ & $12 / 45(26.7 \%)$ & $\begin{array}{l}0.808921 \\
\text { (Pearson Chi-Square) }\end{array}$ \\
\hline Wound complications $=$ Yes & $8 / 37(21.6 \%)$ & $8 / 43(18.6 \%)$ & $\begin{array}{l}0.736601 \\
\text { (Pearson Chi-Square) }\end{array}$ \\
\hline Length of hospitalization & $\begin{array}{l}13.73 \pm 6.0399 \\
(\mathrm{~N}=37)\end{array}$ & $\begin{array}{l}15.61 \pm 5.3666 \\
(\mathrm{~N}=44)\end{array}$ & $\begin{array}{l}0.141240 \\
\text { (Independent Samples Test) }\end{array}$ \\
\hline Disease-free interval & $\begin{array}{l}22.0[4.0,-] \\
(\mathrm{N}=3)\end{array}$ & $\begin{array}{l}23.5[12.0,39.0] \\
(\mathrm{N}=10)\end{array}$ & $\begin{array}{l}1.000000 \\
\text { (Mann-Whitney U) }\end{array}$ \\
\hline
\end{tabular}

Considering the statistical data from the study, we found out a significant association between the relapse of the disease and the suboptimal surgery, (22.2\%) ( $\mathrm{p}_{-}$value $=0.032035$ test Pearson Chi-Square) (Tabel 4)

Tabel 5. Survival analysis acordding to clinical, paraclinical, tumoral and treatment factors

\begin{tabular}{|ccc|}
\hline Pelvic pain & dead & P_value \\
Yes & $33 / 74$ & 0.067264 (Log Rank (Mantel-Cox test) \\
No & $6 / 8$ & 0.108053 (Breslow (Generalized Wilcoxon test) \\
Image appearance Carcinomatosis & & 0.054378 (Log Rank (Mantel-Cox test) \\
Pelvic tumor & $8 / 13$ & 0.185794 (Breslow (Generalized Wilcoxon test) \\
Pelvic tumor, carcinomatosis & $14 / 37$ & \\
FIGO stage & $2 / 2$ & 0.005560 (Log Rank (Mantel-Cox test) \\
I & $2 / 10$ & 0.007230 (Breslow (Generalized Wilcoxon test) \\
II & $1 / 7$ &
\end{tabular}




$\begin{array}{|ccc|}\text { IIIB } & 3 / 4 & \\ \text { IIIC } & 3 / 5 & \\ \text { IV } & 11 / 17 & \\ \text { Cytoreduction } & & \\ \text { Optimal } & 10 / 37 & 0.000803 \text { (Log Rank (Mantel-Cox test) } \\ \text { Suboptimal } & 29 / 45 & \\ \text { histopathological type } & 1 / 1 & 0.011524 \text { (Log Rank (Mantel-Cox test) } \\ \text { Clear cells } & 1 / 2 & 0.021538 \text { (Breslow (Generalized Wilcoxon test) } \\ \text { Endometrioid } & 0 / 3 & \\ \text { Canker } & 2 / 11 & \\ \text { Mucinous } & 5 / 10 & \\ \text { Undifferentiated } & 25 / 47 & 0.000039 \text { (Log Rank (Mantel-Cox test) } \\ \text { Serosus } & 35 / 75 & 0.000058 \text { (Breslow (Generalized Wilcoxon test) } \\ \text { Postoperative treatment } & 2 / 2 & 0.000550 \text { (Log Rank (Mantel-Cox test) } \\ \text { Yes } & 1 / 1 & 0.000600 \text { (Breslow (Generalized Wilcoxon test) } \\ \text { No } & 38 / 81 & \\ \text { Yes } & & \\ \text { No } & \end{array}$

Comparing the survival of the patients with different characteristics we realised a reduced survival in advanced stages of the disease ( $p_{-}$value $=0.005560$ (Log Rank (Mantel-Cox test)), with suboptimal surgery (p_value $=0.000803(\log$ Rank $($ Mantel-Cox test)), with seros histopatological type (p_value $=0.011524$ (Log Rank (Mantel-Cox test), with the absence of adjuvant treatment (p_value $=0.000039$ (Log Rank (MantelCox test) and with the presence of postsurgical complications. (p_value $=0.000550$ (Log Rank (Mantel-Cox test) (Table 5).

Tabel 6. Multivariat regresion Cox - for the criteria with statistically significance at the univariat analisys p-value $<0.05$ and the magnitude coef (B) represents the importance of the predictor Variables in the Equation

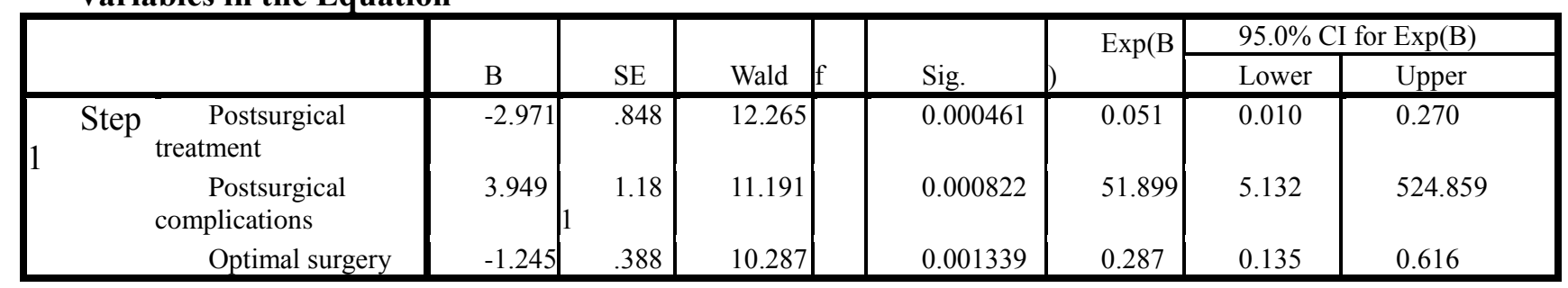

Analyzing the patients survival of the patients with adjuvant chemotherapy versus no adjuvant chemotherapy, we calculated the risk of death in the case of the presence of postsurgery treatment. HR $=0.051,95 \% \mathrm{CI}=(0.13,0.61),(\mathrm{p}$ value $=0.000461) \quad($ Table 4$)-$ Adjuvant chemotherapy is a protection factor. (Figure 2).

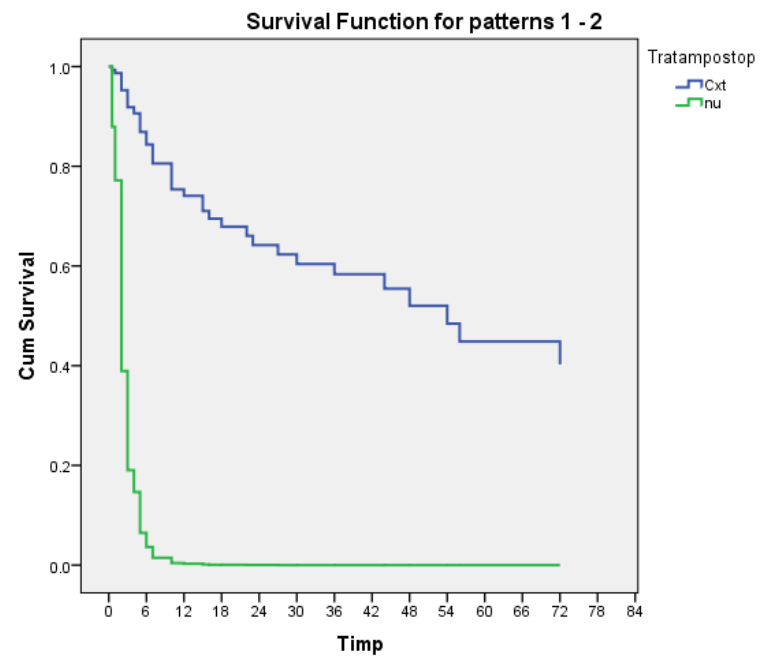

Figure 2. The survival curve Cox according to adjuvant treatment in cases with similar types of surgery and postsurgical complications 
Considering the survival of the patients with no postsurgical complications with those who had postsurgical complications we calculated the risk of death in the case of the group with present complications. $-\mathrm{HR}=51.899,95 \% \mathrm{CI}=(5.132,524.859)(\mathrm{p}$ value $=0.000822)($ Table 6$)-$ The presence of the postsurgical complications is a risk factor.

Comparing the survival of the patients with suboptimal surgery versus optimal surgery we analysed the death risk $-\mathrm{HR}=0.228,95 \% \mathrm{CI}=(0.13,0.61), \quad\left(\mathrm{p} \_\right.$value $=0.001339$ (Figure 3$)-$ Optimal surgery is a protection factor.

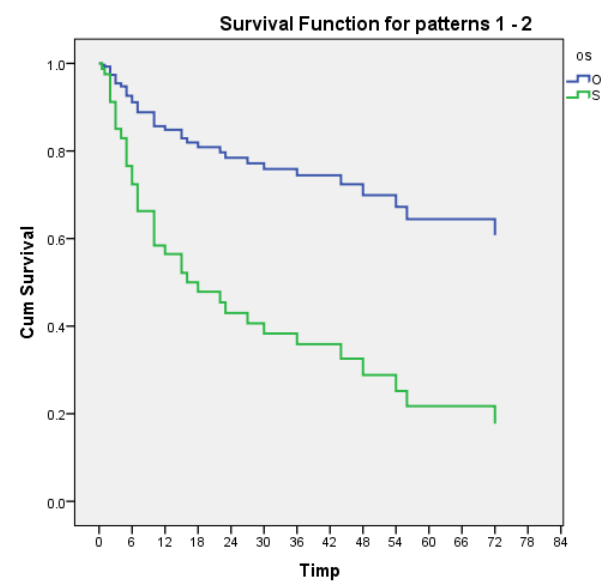

Figure 3. The survival curve Cox according to surgery type in cases with similar types of surgery and postsurgical complications

1. The high value of the marker CA 125, imagistic finding of carcinomatosis, advanced stages III and IV FIGO of the disease and the serous type histopatological are associated with suboptimal type of surgery - prediction factors.

2. Suboptimal surgery is a risk factor for the appeeance of the disease relapse.

3. Suboptimal surgery is an independent risk factor for the survival in patients with ovarian carcinoma.

Ovarian carcinoma is the second type of cancer as frequency but the most deathly cancer for women.[11].

At the present, we still don't have screening methods to diagnose in early stages ovarian carcinoma. Consequently, and also because the patients have usually nonspecific signs and symptoms, approximative $70 \%$ of the cases are diagnosed in advanced stages, with a poor prognosis of survival. The standard treatment for ovarian carcinoma remains the surgical one, followed by the adjuvant chemotherapy. According to GOG (Oncologic Gynecology Group) the optimal surgery is defined with a residual tumor after surgery less than 1 cm.[12].

Thereby, according to the ESGO (2017) ovarian cancer surgical guidelines and recommendation of the Polish society of oncological gynaecology the main purpose of the surgery is complete eradication of the tumor, in the absence of macroscopically tumor after surgery.[13,14].

Despite the fact that the surgery represents the main treatment for ovarian carcinoma, we cannot apply it for all patients. In those cases, with advanced stage of the disease or with poor paraclinical status neoadjuvant chemotherapy remains the best option.[15].

The definition of optimal debulking surgery has changed lately and now it is clear that the chance of better survival is based on the debulking surgery. Any other final outcome of the primary surgery is associated with a poor prognosis.[16].

In conclusion, we can affirm that the residual tumor after surgery is the most important prognosis factor in ovarian carcinoma, but the decision in initially debulking surgery or neoadjuvant chemotherapy followed by the interval surgery remains the key point in the management of the patients.[17,18].

In the current speciality literature, it is mentioned that the primary most important prognosis factor is the type of surgery, more exactly: as the first surgery is more radical (residual tumoral after surgery macroscopically absent) as the chance of survival is better.[19-22]. 


\section{Conclusions}

The high value of the marker CA 125, imagistic finding of carcinomatosis, advanced stages III and IV FIGO of the disease and the serous histopathological type are associated with suboptimal type of surgery - prediction factors.

Relapse of the disease is significantly associated with suboptimal surgery- risk factor

Early postsurgical complications are associated with complex type of surgery.

Suboptimal surgery is an independent prognosis factor for survival in patients with ovarian carcinoma.

Optimal surgery represents a protection factor for survival in patients with ovarian carcinoma.

\section{References}

1. SUCIU N. - Tratat de chirurgie extrapelvina a ovarului - Ed. Universitara Carol Davila 2016; ISBN: 978-973-708-914-4

2. CHU C., HOSKINS W., et al - Glob. Libr. Women's med (ISSN 17562228); 2011 DOI 10.3843/Glowm.10252

3. PUJADE LAURAINE E., RAY COQUARD I., LECURU F. - Ovarian Cancers - 2017; ISBN 9783319321080

4. KATABUCHI H. - Frontiers in Ovarian cancer Scince - 2017; ISBN 978-981-10-4160-0

5. WRIGHT J.D., ANANTH C.V., TSUI J., GLIED S.A., BURKE W.M., LU Y.S., NEUGUT Al., HERZOG T.J. and HERSHMAN D.L. - Comparative effectiveness of upfront treatment startegies in elderly women with ovarian cancer - 120:1246-1254, 2014

6. MEIGS J.V. - Tumors of the female pelvic organs. New York: MacMillian 1934

7. CARTER J., PATHER S., NASCIMENTO M. - Current status of ovarian cancer surgical management. Argument for centralisation of care in Australia - Aust N Z J Obstet Gynaecol. 2018 May 31.

8. GRIFFITHS C.T. - Surgical resection of tumor bulk in the primary treatment of ovarian carcinoma Natl Cancer Inst Monogr 42 101-104, 1975

9. DINCA A.L., DINCA V.G., BIRLA R.D., CONSTANTINOIU S.M. - Preserving fertility in ovarian cancer, Rev.Chim., 70(9), 2019, 3361-3363

10. CALIN M.A., MIHALCEANU E., DEBITA M., RAFTU GH., COSTACHESCU G., MITREA G. - The Modern Chemical Theory of Ovarian Cancer Origin, Rev.Chim., 70(3), 2019, 1026-1029.

11. ALEXANDER J., PATRYCJA TUDREJ, KATARZYNA A. KUJAWA AND KATARZYNA M. LISOWSKA - Advances in ovarian cancer therapy; cancer Chemother Pharmacol.; 81(1); 17-38, 2018

12. DU BOIS A., REUSS A., PUJADE-LAURAINE E., HARTER P., RAY-COQUARD I., PFISTERER J - Role of surgical outcome as prognostic factor in advanced epithelial ovarian cancer: a combined exploratory analysis of 3 prospectively randomized phase 3 multicenter trials: by the Arbeitsgemeinschaft Gynaekologische Onkologie Studiengruppe Ovarialkarzinom (AGO-OVAR) and the Groupe d'Investigateurs Nationaux Pour les Etudes des Cancers de l'Ovaire (GINECO). Cancer.; 115(6): 1234-44. 2009;

13. E. SGO. GUIDELINES EsoGO. Advanced 9stage III-IV) ovarian cancer surgery. Quality indicators. Complete report. Prague: ESGO; 2015

14. BASTA A., BIDZINSKI M., BIENKIEWICZ A., BLECHARZ P., BODNAR L., JACH R., KNAPP P., KOJS Z., KOTARSKI J., MARKOWSKA J., MISIEK M., SZURKOWSKI J, WICHEREK L., SAWICKI W., TIMOREK A., BAHYRYCZ J., MADRY R. - Recommendation of the Polish society of oncological gynaecology Ginekol Pol. 2015

15. IBEANU OA., BRISTOW RE. - Predicting the outcome of cytoreductive surgery for advanced ovarian cancer - Int J Gynecol Cancer.; 10:S1-S11. 2010

16. CHI DS., EISENHAUER EL., ZIVANOVIC O., SONODA Y., ABU-RUSTUM NR., LEVINE DA., et all. - Improved progression-free and averall survival in advanced ovarian cancer as a result of a change in surgical paradigm. Gynecol Oncol.; 114:26-31.2009 
17. WIMBERGER P., LEHMANN N., KIMMIG R. et all. - Prognostic factors for complete debulking in advenced ovarian cancer and its impact on survival: an exploratory analysis of a prospectively randomized phase III study of the Arbeitsgeme in schaftGynaekologische Onkologie Ovarian Cancer Study Group (AGO-OVAR). Gynecol Oncol.; 106:69-74. 2007

18. LLUECA JA., HERRAIZ JL., CATALA C., et all; MUAPOS Working Group. Effectiveness and safety of cytoreduction surgery in advanced ovarian cancer: initial experience at a university general hospital. J Clin Gynecol Obstet.; 4:251-257. 2015.

19. DINCA A.L., DINCA V.G., CONSTANTINOIU S.M., BIRLA R.D., Screening in ovarian neoplasm, Rev. Chim. 70(10), 2019, 3687-3688

20. DINCA A.L., DINCA V.G., CONSTANTINOIU S.M., BIRLA R.D., Importance of surgical treatment in ovarian neoplasm, Rev. Chim.,71(1) 2020, 371-377.

21. CALIN M.A., MIHALCEANU E., DEBITA M., RAFTU GH., COSTACHESCU G., MITREA G. - The Modern Chemical Theory of Ovarian Cancer Origin, Rev.Chim., 70(3), 2019, 1026-1029.

22. PIRTEA L., GRIGORAS D., SECOSAN C., SAS I., ILINA R., JITARIU A.A., MEDERLE O.A., Clinical and Histopathological Parameters Correlate with Microvessel Density but Not with Vascular Endothelial Growth Factor Expression in Ovarian Cance, Rev.Chim., 69(5), 2018, 1173-1178

Manuscript received: 2.04 .2020 